811.161.1'373.7

811.161.1'367

https://doi.org/10.18485/sj.2017.22.1.3

КАЦЮБА Л.Б.

РЭУ им. Г.В. Плеханова

кафедра руского языка
Оригинални научни рад

Примљен: 15. 07. 2016.

Прихваћен: 15. 12. 2016.

\title{
СЕМАНТИКА СИНТАКСИЧЕСКИХ ОТНОШЕНИЙ В ПРОЦЕССУАЛЬНЫХ ПРЕДЛОЖНО-ПАДЕЖНЫХ КОНСТРУКЦИЯХ (НА МАТЕРИАЛЕ РУССКИХ ПАРЕМИЙ)
}

\begin{abstract}
В настоящей работе рассматривается объектное значение приглагольного дательного падежа в конструкциях с предлогом $\kappa$ в паремиях. Основное значение приглагольного дательного падежа в паремиях, как и вне паремий, - значение дальнейшего, или косвенного, объекта (то есть значение адресата, пункта, куда направлено действие, общей цели, направления). Дательный падеж с объектным значением - наиболее продуктивная форма для процессуальных единиц, управляющих дательным падежом имени в паремиях. Дательный падеж с объектным значением в исследуемых конструкциях употребляется с глаголами четырех основных семантических категорий: действия и деятельности, бытия, состояния, отношения, где на первое место вышли глаголы семантической категории действия и деятельности. Анализ семантической структуры глагола проведен на основе комплексного словаря русских глаголов в соответствии с семантической классификацией русской глагольной лексики, в которой семантизация глагольных лексем соответствует принципам иерархии, вариативности и пересекаемости глагольных классов.
\end{abstract}

Ключевые слова: приглагольный дательный падеж, значение косвенного объекта, конструкции с предлогом $\kappa$, процессуальные единицы, паремиологический жанр.

"larrakatz@yandex.ru 
Семантико-грамматические исследования в области фразеологии и паремиологии сегодня не исчерпаны и по-прежнему актуальны. Функционально-прагматический уровень изучения языковых единиц в лоне паремиологии расширяет границы исследования фразеологии в целом, обогащая при этом процесс системного изучения языковых единиц новыми лингвистическими фактами.

Наш интерес к паремиологическим единицам как специфическому материалу разного рода исследований - семантико-грамматических, лингвокультурологических, психолингвистических и лингводидактических - является постоянным и неизменным. Как объект лингвистического внимания выбранные единицы содержательны, богаты по разнообразию предложно-падежных конструкций и глагольных лексем, кроме того, они являются ценным культурным фоном, который нацеливает исследователя на дальнейшую работу. Материал оригинальной картотеки представлен с соблюдением орфографии и пунктуации публикуемых в сборниках текстов.

Под паремией в настоящем исследовании понимается минимальный текст, состоящий из одного или нескольких предложений с определенной синтаксической структурой и лексическим составом. В общетеоретическом смысле мы определяем паремию как: 1) пословицу; высказывание (изречение, суждение), относящееся к пословице; 2) краткое образное устойчивое высказывание (часто, употребляемое в переносном значении), синтаксически оформленное как простое или сложное предложение (которое иногда может состоять из нескольких предложений), отражающее обобщенную формально закрепленную ситуацию, возведенную в формулу, излагающее важную истину, наставление, правила или принципы поведения, нравственные законы, сформулированные на основе жизненного опыта (подробнее об этом см. [Кацюба 2015: 5-9]).

В проспекте статьи мы обратились к исследованию семантики синтаксических отношений, реализованных в конструкции «глагол + предложно-падежная форма имени в дательном падеже», материалом для которого послужили русские паремии из сборников В.И. Даля [Даль 1984], В.П. Аникина [Аникин 1988], Ю.Г. Круглова [Круглов 1990], В.И. Зимина [Зимин 2012] и др.

Анализ паремий, проведенный с точки зрения наличия в них глаголов, управляющих дательным падежом имени в предложных конструкциях, позволил описать семантику дательного падежа в соотношении с семантикой процессуальной единицы, отметить в проанализированных конструкциях наиболее продуктивные семантические категории глагола, проследить функционирование предлогов.

В рамках данной статьи мы рассматриваем объектное значение приглагольного дательного падежа в конструкциях с предлогом $\kappa$. 
Как отмечал В.В. Виноградов, «в падежных формах имени < ..> отражается понимание связей между предметами, явлениями, действиями и качествами в мире материальной действительности. Тут объединяется множество грамматических категорий, выражающих семантические оттенки пространственных, временных, <..>, целевых и других отвлеченных отношений. Формы и функции падежей соотносительны с грамматической системой предлогов, с присущими им значениями» [Виноградов 2001: 144]. В традиционном понимании приглагольный дательный падеж служит для обозначения процесса, действия, направленного в сторону другого предметного понятия, «ему предназначается, к нему склонно, к нему направлено» [Виноградов 2001: 145].

Употребление дательного падежа, который «своим названием выражал одну из своих функций» [Виноградов 2001: 144], представляет собой целостную, непротиворечивую семантическую систему. Основное значение приглагольного дательного - значение дальнейшего, или косвенного, объекта (то есть значение адресата, пункта, куда направлено действие). Форма и значение дательного объектного не противоречат друг другу: объект в форме дательного падежа по функции в предложении и по своему значению является косвенным объектом.

Как показало исследование, дательный падеж с объектным значением - наиболее продуктивная форма для процессуальных единиц, управляющих дательным падежом имени в паремиях. В исследованных конструкциях выделены два типа «лексических» (термин употреблен вслед за Г.А. Шигановой [Шиганова 2001: 11]) непроизводных предлогов - $к$ и по.

В нашей картотеке дательный падеж с объектным значением в конструкциях с предлогом $\kappa$ употребляется с глаголами четырех основных семантических категорий: действия и деятельности, бытия, состояния, отношения. Анализ семантической структуры глагола проведен на основе комплексного словаря русских глаголов в соответствии с семантической классификацией русской глагольной лексики, в которой семантизация глагольных лексем соответствует принципам иерархии, вариативности и пересекаемости глагольных классов [Бабенко 1999].

Глаголы семантической категории действия и деятельности представили обширную группу с наиболее активным корпусом глаголов лексикосемантической группы движения со значениями направленного движения, ориентированного относительно исходного и конечного пунктов; движения в определенном направлении куда-либо, к кому-либо по твердой поверхности или в жидкой, воздушной среде (бежсать, валить в значении «двигаться», ехать, идти, пойти, взойти, ходить, пльтьь и др.): $\boldsymbol{К}$ милому Сереженьке сами бегут ноженьки; Ехал к брату, а заехал к свату; Ехал к вам, да заехал $\boldsymbol{\kappa}$ нам; К босому за сапогами пошел; Где беда ни была, а к нам пришла; $\boldsymbol{K}$ 
собаке подходи сзади, а к лошади - спереди; $\boldsymbol{K}$ сонному попу на исповедь не ходят; К любящему и страх не идет; Придет солнышко и к нашим окошечкам; Взойдет солнце и к нам на двор; Деньги идут к богатому, а зльлни - к убогому; Был Филя в силе - все други к нему валили, а пришла беда - все прочь со двора; К нашему берегу не плывет красно дерево - либо чурка, либо палка; Кума к куме - хоть в решете, да припльвет; К добру гребись, от худа шестом суйся.

Кроме группы движения категория действия и деятельности представлена глаголами

- присоединения: Чистое к поганому не пристанет; $\boldsymbol{\kappa}$ миру приставай, а от мира не отставай; К кафтану совести не пришьешь; Слово к делу не пришьешь; К зяблому лииу да снег подсыпаешь; От бога отказаться - к сатане пристать;

- физического воздействия на объект: Все может случиться и богатый к бедному стучится; Человек родится, а пальцы у него уже к себе гнутся; Бей жену к обеду, а к ужину опять;

- приближения: Фита да ижица - к ленивому плеть ближится; Хорошо около костра щчепу огребать: дай подсесть кмешку, и я нагребу;

- речевой деятельности: (К пиву едется), к слову молвится; (К пиру пошлось), к слову молвилось; Пословица к слову молвится; Приговорил к себе во двор, ан вылиел вор;

- $\quad$ социальной деятельности: Повадишься к вечерне-не хуже харчевни: ныне свеча - ан шуба с плеча; Не болела, не горела, а к смерти приспела;

- помещения (одевания): Крой кафтан новый, а к старому примеряй!;

- перемещения объекта: Не носи сору к соседнему забору, в соре много вздору;

- интеллектуальной деятельности: Хочешь покою - готовься к бою и др.

Глаголы семантической категории отношения всегда обозначают направленность действия на объект, предмет; они всегда находятся между двумя предметными субстанциями: лицо, предмет (или субъект) и объект, на который направлено действие. В проанализированных конструкциях представлена немногочисленная группа глаголов социальных отношений - глаголы влияния: Хорошая жена - к дому приручает, плохая - от дома отлучает; Собака привыкает к человеку, а кочка - к омму. 
Глаголы семантической категории бытия представлены лексико-семантическими группами существования: Где муха ни летала, а к пауку попала; Где пичужка ни летала, а к нам в клетку попала; прекращения действия: Врал до обеда, да и к ужину оставил. В материале картотеки единично представлены глаголы эмоционального качественного состояния: Кто глянется, к тому и сердие тянется.

Наблюдение за семантической структурой глаголов заданных конструкций с зависимым дательным падежом в паремиологическом тексте закрепляет понимание того, что все семантические категории, а также выделенные внутри категории лексико-семантические группы и подгруппы тесно связаны друг с другом разными типами семантических отношений, в частности, синонимическими; глаголы могут относиться к какой-либо одной категории, но иметь семы другой (других) категорий. Наш материал показал, что сема приближения, присоединения, направленного участия в процессе, включения в процесс присуща большинству глаголов исследованных конструкций в паремиях.

С категорией падежа грамматически и функционально связана система предлогов. В этой взаимосвязи наблюдается определенное семантическое соответствие. Функционально однородные, синтаксически определенные предлоги дательного падежа служат для выражения падежного значения, усиливая, подчеркивая, дополняя его и поддерживая стройную единую систему грамматики дательного падежа.

Исследование семантических отношений в синтаксических конструкциях невозможно без изучения семантики предлога, которое проведено нами с помощью данных, зафиксированных в словарях [Даль 1994, Золотова 2006, Евгеньева 1983]. Предлог к (кому, чему) относится к разряду предлогов, синкретично выражающих значения субкатегорий «объектные отношения» и «обстоятельственные отношения», которые зачастую тесно переплетены. Так, в паремиях Ехал к Фоме, а заехал к куме; $\boldsymbol{К}$ босому по лапти пошел; То не мудрено, что к воеводе принесено; Прощай, матушка Русь: я к теплу тянусь; Нищий болезней ищет, а к богатому они сами идут и др. в большей степени предлог обнаруживает сему объектности с различными оттенками и используется при обозначении предмета или лица, к которым направлено действие. В паремиях Не суйся (к чему? куда?) к капусте, как припустят; Где ворона ни летала, а к ястребу в когти попала (к кому? куда?); Повечеру пороша выпала; а к белу свету и порошица пропала (когда?); Не к тому говорится (к чему? зачем? с какой целью?), чтоб браниться, а чтоб в ладах жить и др. обстоятельственная сема выходит на второе или первое место. Это наблюдение соотносится с утверждением о значении дательного падежа, который в таких конструкциях всегда выражает отношения «приближения» и другие с объектными, собственно- и обстоятельственно-характеризующими 
значениями [Акопян 1974]. Синкретично проявленные субкатегориальные (объектные, объектно-обстоятельственные, обстоятельственные) значения предлога $\kappa$, оформляющего приглагольный дательный, составляют «совокупность его семантических реализаций < ..>, или его семантическую структуру» [Ярцева 1998: 394], и указывают на то, что внутри падежа существует свой круг значений, соотносимый со значениями предлога как лексической и синтаксической единицы.

В результате исследования семантики синтаксических отношений, реализованных в конструкции «глагол + предложно-падежная форма имени в дательном падеже» на материале русских паремий можно отметить следующее.

Основное значение приглагольного дательного падежа в паремиях, как и вне паремий, - значение дальнейшего, или косвенного, объекта (то есть значение адресата, пункта, куда направлено действие, общей цели, направления). Дательный падеж с объектным значением - наиболее продуктивная форма для процессуальных единиц, управляющих дательным падежом имени в паремиях. Семантико-синтаксическая сфера реализации приглагольного дательного падежа с предлогом $\kappa$ в паремиологическом тексте четко очерчена и непротиворечива, что является конструктивной особенностью дательного падежа.

В конструкциях с предлогом $\kappa$ дательный объектный употребляется с глаголами четырех основных семантических категорий: действия и деятельности, бытия, состояния, отношения, где на первое место вышли глаголы семантической категории действия и деятельности. Сема действия, абстрактная по сути, проявляется в глаголах всех семантических категорий. Русская лексика многозначна; полисемантичные глаголы характеризуются своей принадлежностью одновременно к нескольким семантическим категориям в зависимости от характера своего значения. Наблюдение за семантической структурой глаголов заданных конструкций закрепило понимание того, что все семантические категории взаимосвязаны, что учитывалось при семантизации глагольных лексем. Наш материал показал, что сема присоединения, приближения, включения в процесс, направленного участия в процессе реализована в большинстве глаголов исследованных конструкций в паремиях.

В попытке изучения семантической природы предлога $к$ мы опирались на данные, зафиксированные в нормативных, толковых и синтаксических словарях. Согласно исследованию, предлог $\kappa$ относится к разряду предлогов, синкретично выражающих значения субкатегорий «объектные отношения» и «обстоятельственные отношения». Синкретизм синтаксических отношений в данных конструкциях нашел выражение и в паремиях. 
В заключение отметим, что закономерная взаимосвязь семантики глагола, семантики предлога и значения падежа качественно по-новому проявила себя в паремиологическом тексте как специфической части русского речевого узуca. С одной стороны, паремиологическая грамматика является частью общей грамматики русского языка и основана на тех же принципах, с другой стороны, языковые факты особенно ярко раскрываются в лоне паремиологического текста, что делает паремию благодатным источником познания языка.

\section{ЛИТЕРАТУРА}

Акопян 1974: Структурно-семантическое исследование глагольных конструкиий с зависимым дативом в русском языке / Акопян Р.С. Автореф. дис. ... канд. филол. наук. - Казань. - 23 с.

Аникин 1988: Русские пословищы и поговорки / под ред. В.П. Аникина. - М.: Худож. лит. -431 с.

Бабенко 1999: Толковый словарь русских глаголов: идеографическое описание. Английские эквиваленты. Синонимы. Антонимы / под ред. Л.Г. Бабенко. - М.: АСТ-ПРЕСС. -704 c.

Виноградов 2001: Русский язык (Грамматическое учение о слове) / Виноградов В.В., под ред. Г.А. Золотовой. - 4-е изд. - М.: Рус. яз. -720 с.

Даль 1984: Пословищы русского народа / Даль В.И. Сборник. В 2-х т. - М.: Худож. лит.

Даль 1994: Толковый словарь живого великорусского языка / Даль В.И. В 4-х т. - Т. 2: И-О. - М.: ТЕРРА. -784 c.

Евгеньева 1983: Словарь русского языка / под ред. А.П. Евгеньевой. В 4-х т. - 2-е изд., испр. и доп. - Т.2. К-О . - М.: Русский язык. -736 с.

Зимин 2012: Словарь-тезаурус русских пословии, поговорок и метких выражений / Зимин В.И. - М.: АСТ-ПРЕСС КНИГА. - 736 с.

Золотова 2006: Синтаксический словарь: репертуар элементарных единич русского синтаксиса / Золотова Г.А. - М.: Едиториал УРСС. $-440 \mathrm{c}$.

Кацюба 2015: Личо глагола в русских пословищах: семантико-грамматические и лингвокультурологические аспекты / Кацюба Л.Б. Монография. - М.: МЭСИ. -240 с.

Круглов 1990: Русские народные загадки, пословиџы, поговорки / сост. Ю.Г. Круглов. - М.: Просвещение. -335 с. 
Шиганова 2001: Система лексических и фразеологических предлогов в современном русском языке / Шиганова Г.А. Монография. - Челябинск, изд-во Челяб. гос. пед. Ун-та. - 454 с.

Ярцева 1998: Языкознание. Большой энциклопедический словарь / гл. ред. В.Н. Ярцева. -2-е изд. - М.: Большая Российская энциклопедия. $-685 \mathrm{c}$.

\section{СЕМАНТИКА СИНТАКСИЧКИХ ОДНОСА У ПРОЦЕСУАЛНИМ ПРЕДЛОШКО-ПАДЕЖНИМ КОНСТРУКЦИЈАМА \\ (НА МАТЕРИЈАЛУ РУСКИХ ПАРЕМИЈА)}

\section{Резиме}

У раду се разматра објекатско значење адвербалног датива, тј. датива који је условљен рекцијом глагола, у конструкцијама с предлогом $\kappa$ у паремиолошком жанру руског језика. Под паремијом у овом истраживању подразумева се минимални текст који се састоји од једног или од неколико реченица с одређеном синтаксичком структуром и лексичким саставом. Са општетеоријског становишта паремија је 1) пословица, 2) кратки сликовити устаљени исказ (често у преносном значењу) који одражава уопштену формално одређену ситуацију која је уобличена као формула и у којој се излаже важна истина, поука, правила или принципи понашања или морални закони који су формулисани на основу животног искуства.

Основно значење адвербалног датива у паремијама, као и ван паремија, јесте значење даљег или индиректног објекта (тј. значење адресата, места у које је усмерена радња, заједничког циља, правца). Датив у објекатском значењу је у паремијама најпродуктивнија форма процесуалних јединица са именском рекцијом у дативу.

Датив у објекатском значењу у испитиваним конструкцијама употребљава се с глаголима четири основне семантичке категорије: радње и делатности, постојања, стања и односа, али доминантно место имају глаголи семантичке категорије радње и делатности.

Анализа семантичке структуре глагола спроведена је на основу комплексног речника руских глагола у складу са семантичком класификацијом руске глаголске лексике у којој семантизација глаголских лексема одговара принципима хијерархије, варијативности и преплитању семантичих поља глаголских класа.

Кључне речи: адвербални датив, значење индиректног објекта, конструкције с предлогом $\kappa$, процесуалне јединице, паремиолошки жанр.

Лариса Б. Качјуба 